\title{
Migratory movement and population structure of humpback whales (Megaptera novaeangliae) in the central and eastern North Pacific
}

\author{
C. Scott Baker ${ }^{1}$, Louis M. Herman ${ }^{1}$, Anjanette Perry ${ }^{1}$, William S. Lawton ${ }^{2}$, Janice M. \\ Straley ${ }^{3}$, Allen A. Wolman ${ }^{4}$, Gregory D. Kaufman ${ }^{5}$, Howard E. Winn ${ }^{6}$, John D. Hall ${ }^{7}$, \\ John M. Reinke ${ }^{8}$ \& Jan Östman ${ }^{9}$
}

\author{
' Kewalo Basin Marine Mammal Laboratory and Departments of Zoology, Psychology, and Oceanography, University of \\ Hawaii, 1129 Ala Moana Boulevard, Honolulu, Hawaii 96814, USA \\ ${ }^{2}$ Global Naturalists, 521 North 75th Street, Seattle, Washington 98103 , USA \\ ${ }^{3}$ P.O. Box 273, Sitka, Alaska 99835, USA \\ 4 National Marine Mammal Laboratory, 7600 Sand Point Way NE, Building 4, Seattle, Washington 98115, USA \\ ${ }^{5}$ Pacific Whale Foundation, Suite 303 Azeka Place, Kihei, Hawaii 96753, USA \\ ${ }^{6}$ Graduate School of Oceanography, University of Rhode Island, Narragansett, Rhode Island 02882, USA \\ ${ }^{7}$ Solace Enterprises, P.O. Box 4885, Anchorage, Alaska 99510, USA \\ ${ }^{8}$ 9119-17th Avenue NE, Seattle, Washington 98115, USA \\ ${ }^{9} 273$ Applied Sciences, University of California, Santa Cruz, California 95064, USA
}

\begin{abstract}
Photographs of individually identified humpback whales Megaptera novaeangliae were collected in regions throughout the central and eastern North Pacific during the years 1977 to 1983 . A comparison of these photographs revealed extensive movement between seasonal habitats. Whales found wintering near Hawaii traveled to summer feeding regions throughout the coastal waters of Alaska. Whales wintering near Mexico were found in Alaskan feeding regions and near the Farallon Islands off central California. Little exchange was found between the 2 wintering grounds or among the 5 summering grounds studied. Fidelity to a given feeding region was demonstrated by a high proportion of migratory return. Evidence of fidelity to a given wintering ground was less conclusive. The coloration of humpback whale flukes showed a longitudinal cline across the 5 feeding regions. Flukes of whales from the easternmost feeding regions were, on average, darker than those from the westernmost feeding regions. Whales in Hawaii and Mexico were similar in fluke coloration and the average coloration on both wintering grounds was intermediate between the extremes of the feeding regions. We propose that humpback whales in the eastern and central North Pacific form a single 'structured stock' consisting of several geographically-isolated 'feeding herds' which intermingle on 1 or more wintering grounds. Mark-recapture analyses of resighting data indicate that the Hawaiian wintering congregation is 4 to 6 times larger than the southeastern Alaska feeding herd. Within a structured stock, sets of whales interact with different probabilities in each seasonal habitat. This, in turn, has important implications for the social organization and management of these whales.
\end{abstract}

\section{INTRODUCTION}

Humpback whales Megaptera novaeangliae, in most oceans of the world, form sub-populations referred to in the whaling literature as 'stocks'. In the southern hemisphere, Mackintosh (1965) recognizes 6 stocks distributed around the Antarctic continent during the austral summer. During the winter, each stock migrates towards the equator to its own coastal or insular breeding ground in tropical or near-tropical waters. Chittleborough (1965) reviewed the results of discovery-tag marking and recovery from the 2 stocks which feed in the Antarctic Ocean south of Australia. He concluded that these stocks show strong fidelity to breeding grounds on opposite sides of the Australian continent even though some intermingling of the stocks may take place during the feeding season.

Variation in the coloration of humpback whales has also been used to characterize different stocks in the southern hemisphere (Lillie 1915, Mathews 1937). 
Omura (1953) summarized Japanese whaling data showing a clinal decrease in the proportion of darkly pigmented whales among the South Atlantic stock eastward to the eastern Australian and New Zealand stock. Chittleborough (1965), in examining Australian whaling data, agreed with Omura in differentiating the western and eastern Australian stocks based on color differences as well as discovery-tag marking and recovery.

The recent use of natural markings and photographic documentation to identify individual humpback whales (photo-identification) has provided considerable data on migratory movement and population structure in the North Atlantic (Katona et al. 1979, Katona \& Whitehead 1981). These data indicate that humpback whales segregate during the summer in several geographically-isolated feeding regions of the North Atlantic but congregate during winter on the Silver and Navidad Banks near Puerto Rico (Katona \& Whitehead 1981, Whitehead 1982, Martin et al. 1984). Some North Atlantic humpback whales also winter near the Cape Verde Islands off Africa, but this group is not well documented (Winn et al. 1981). No systematic differences in the coloration of North Atlantic humpback whales are reported (True 1904).

The migratory movement and stock segregation of humpback whales in the North Pacific is poorly described. Kellogg (1929), using only the observations of early whalers (Scammon 1874, Andrews 1916), suggested that humpback whales in the North Pacific are divided into an American stock and an Asian stock. He proposed that the American stock breeds in the waters off the west coast of Mexico and travels northward along the coast of North America to feeding grounds in the Gulf of Alaska, the Bering Sea, and near the Aleutian Islands. The Asian stock was thought to winter near the Ryukyu and Bonin Islands, south of Japan, and to travel north to feeding areas in the Sea of Okhotsk and along the Kamchatka peninsula. Although Rice (1978) suggested that whales from the Hawaiian wintering grounds are part of an extended American stock, Kellogg (1929) did not consider this group and may have been unaware of its existence (Herman 1979).

Discovery-tag marking and recovery has provided little data to clarify Kellogg's (1929) proposal. Of the 514 whales tagged in the North Pacific, only 22 were recovered and only 9 of these showed long-range migratory movement (Ivashin \& Rovnin 1967, Nishiwaki 1967, Ohsumi \& Masaki 1975, Rice 1978). All of this movement was between the Ryukyu and Bonin Islands to the south of Japan and feeding areas in the eastern Bering Sea. Although a number of authors comment on the coloration of whales from different regions of the North Pacific (Pike 1953, Tomilin 1957, Nishiwaki
1959, 1962, Herman \& Antinoja 1977, Glockner-Ferrari \& Venus 1983), their methods are not sufficiently similar to allow reliable comparisons.

The photo-identification of humpback whales in the North Pacific has documented the movement of humpback whales between the following seasonal habitats: (1) Hawaii and southeastern Alaska (Baker et al. 1982, 1983b, Darling \& Jurasz 1983); (2) Hawaii and Prince William Sound, Alaska (Baker et al. 1983b, Darling \& McSweeney 1985); (3) Hawaii and the Gulf of Alaska west of Prince William Sound (Baker et al. 1983b); (4) Mexico and southeastern Alaska (Lawton et al. 1979, Baker et al. 1985); and (5) Mexico and Hawaii (Darling \& Jurasz 1983). Short-range movement through the Hawaiian Islands and within southeastern Alaska has also been demonstrated through photo-identification (Herman \& Tavolga 1980, Baker \& Herman 1981, Baker et al. 1982, 1983a).

Here we report the results of an extensive comparison of individual identification photographs collected in known feeding and breeding grounds of the central and eastern North Pacific. The photographs were taken as part of 8 independent research projects involving the authors. The combined data provide a more complete picture of the migratory movement and population structure of the North Pacific humpback whales than would have been possible from any single study.

\section{METHODS}

Each of the 8 studies summarized in this paper provided information from different years or regions of the North Pacific across the 7 yr period from 1977 to 1983. Although the regions and study periods differed in each project, the general methods of data collection were similar.

Photographic methods. Humpback whales were observed from vessels and photographed with $35 \mathrm{~mm}$ single-lens reflex cameras equipped with $300 \mathrm{~mm}$ telephoto or 70 to $210 \mathrm{~mm}$ zoom lenses. High-speed blackand-white or color film was used. In all cases we attempted to obtain clear photographs of the ventral surface of each whale's tail flukes for the purpose of individual identification.

From each observation of a whale or group of whales, the best photograph of each individual's flukes was assigned a 'fluke observation' number. Information on the location, date of sighting, and social affiliation of each fluke observation was stored in a data retrieval file at the University of Hawaii Computing Center. During the matching of fluke photographs a whale that was sighted on more than 1 occasion was also assigned an 'animal' number. The animal number allowed us to recall all fluke observations, or sightings, 
of that individual. Thus, an individual animal was represented by its observation number if it was seen only once, or by its animal number if it was seen more than once.

All fluke observation photographs were judged to be of either good, fair, or poor quality. Good and fair quality photographs showed at least $50 \%$ of both flukes at an angle sufficiently vertical to distinguish the shape of the flukes' trailing edges. For the purposes of this study poor quality photographs were deleted from the data set and the remaining group was examined by at least 2 researchers experienced with photographic data. Many of the photographs used in this paper are also on file with the Photographic Identification Storage and Retrieval System (PISAR) at the National Marine Mammal Laboratory, Seattle, Washington, USA.

Study locations and periods. Research effort was concentrated in 7 regions of the central and eastern North Pacific (Fig. 1). Two of these regions are winter habitats or breeding grounds: (1) the main Hawailan Islands, and (2) the west coast of Mexico, including the Islas Tres Marias and the Islas de Revillagigedo. Five of the regions are primarily summer habitats or feeding grounds: (1) the Farallon Islands off the coast of central California; (2) southeastern Alaska, including the Alexander Archipelago; (3) Yakutat Bay, Alaska; (4) Prince William Sound, Alaska; and (5) the Gulf of Alaska west of Prince William Sound (subsequently referred to as the western Gulf of Alaska).

Photographs were collected in Hawail during 1977 to 1983 from late January to early April, the period of peak seasonal abundance on the Hawaiian wintering grounds (Herman \& Antinoja 1977, Herman et al. 1980, Baker \& Herman 1981, Baker \& Herman 1984a). Whales were photo-identified in the Revillagigedo Islands during March of 1978 and near the Islas Tres Marias during March of 1980. Photographs were collected in southeastern Alaska during the summers of 1979 to 1983 and during the 'late seasons' (November to February) of 1979 to 1982 (Baker et al. 1985). Whales were photo-identified in Yakutat Bay and the western Gulf of Alaska during the summer of 1980 (Rice \& Wolman 1982) and in Prince William Sound during the summers of 1977 (Hall 1979), 1980 (Rice \& Wolman 1982), and 1982. Photographs were collected in the

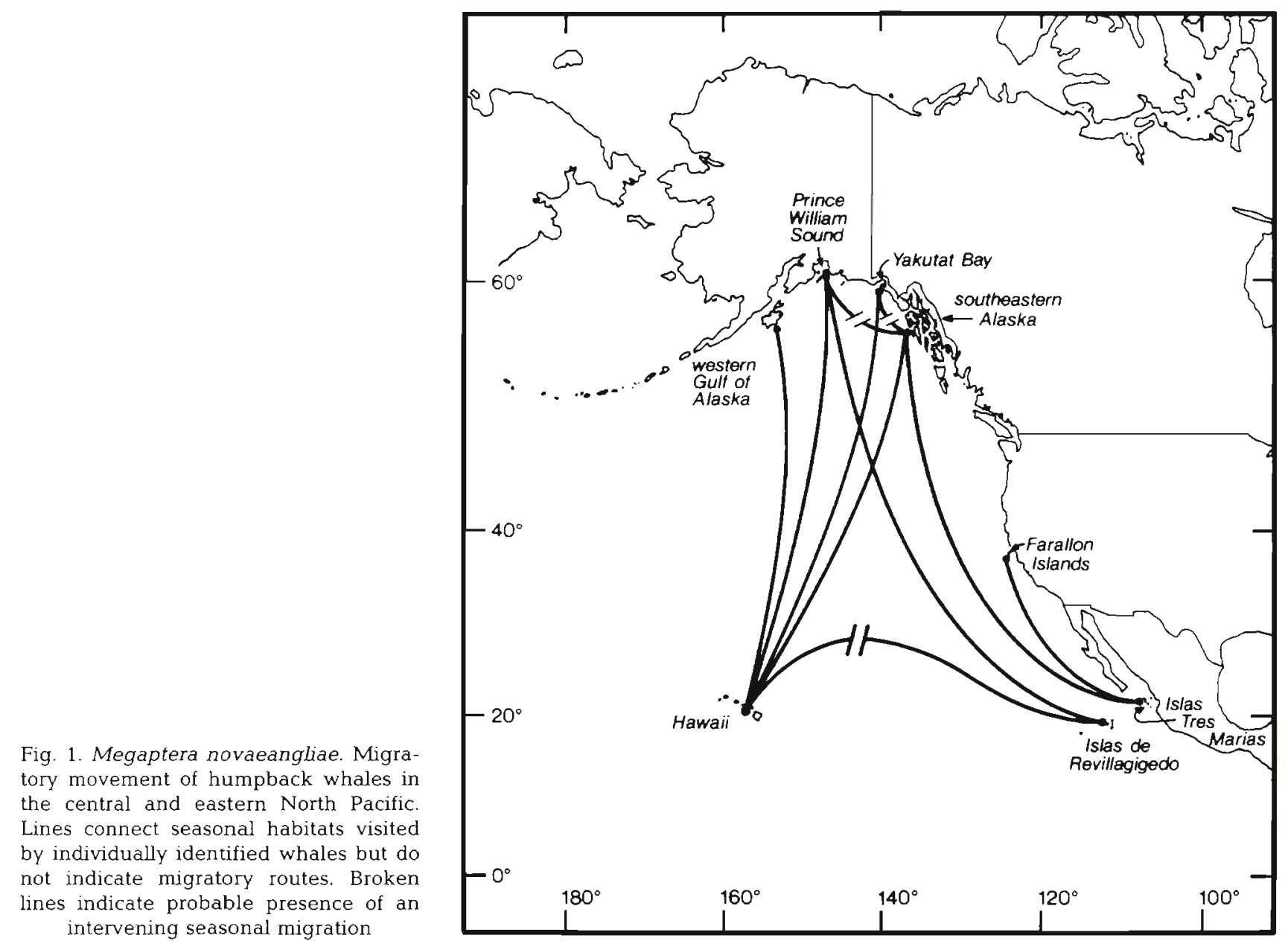


Farallon Islands on $18 \mathrm{~d}$ between June and October of 1983.

\section{RESULTS}

\section{Regional return}

Fluke photographs were compared hierarchically beginning with those taken in the same region and year. Within-year-and-region resights were then deleted from each sample leaving only 1 sighting of each individual in any given year and region (Tables 1 \& 2). The yearly sightings from each region were next compared to determine the number of years an individual was seen in a given region. Individual whales were sighted repeatedly in most of the regions where photographs were collected in more than 1 year (Table 3). Subtracting the resights of whales seen in more than 1 year resulted in the total number of individuals seen in that region. In southeastern Alaska, 154 of the 326 individuals $(47.2 \%)$ were sighted in more than 1 of the study years. Three whales were seen in all 5 study years. In Hawaii, 83 of the 604 individuals $(13.7 \%)$ were sighted in more than 1 study year. No whales were seen in all 7 of the study years. In Prince William Sound, 8 of the 55 individuals $(14.5 \%)$ were seen in more than 1 study year. Mexico was the only region sampled in more than 1 year that did not have some resights across years.

\section{Regional exchange}

A comparison of photographs among the 5 feeding regions and between Hawaii and Mexico revealed very little exchange within a seasonal habitat

Table 2. Study periods and data sources for each of the feeding regions

\begin{tabular}{|c|c|c|c|c|}
\hline Region & Year & Study period & Identified whales & Data source \\
\hline \multirow[t]{7}{*}{ Hawaii } & 1977 & Jan-Mar & 9 & Herman \\
\hline & 1978 & Jan - Mar & 19 & Herman \\
\hline & 1979 & Feb - Mar & 56 & Herman \\
\hline & 1980 & Jan - Apr & 130 & Herman \& Baker \\
\hline & 1981 & Jan - Apr & 175 & Herman, Baker \& Kaufman \\
\hline & 1982 & Mar - Apr & 115 & Herman, Baker \& Kaufman \\
\hline & 1983 & Jan - Mar & 209 & Herman \& Baker \\
\hline \multirow[t]{2}{*}{ Mexico } & 1978 & Mar & 28 & Winn \\
\hline & 1980 & Mar & 15 & Lawton \\
\hline
\end{tabular}

Table 1. Study periods and data sources for each of the wintering regions

\begin{tabular}{|c|c|c|c|c|}
\hline Region & Year & Study period & Identified whales & Data source \\
\hline Southeastern Alaska & $\begin{array}{l}1979 \\
1980 \\
1981 \\
1982 \\
1983\end{array}$ & $\begin{array}{l}\text { Jun }-F_{e b}{ }^{1} \\
\text { Jul }-J_{a n}^{1} \\
\text { Jul }- \text { Dec } \\
\text { Jul - Dec } \\
\text { Jul - Sep }\end{array}$ & $\begin{array}{r}83 \\
122 \\
147 \\
175 \\
45\end{array}$ & $\begin{array}{l}\text { Lawton \& Straley } \\
\text { Lawton, Straley \& Herman } \\
\text { Baker, Herman \& Straley } \\
\text { Baker, Herman \& Straley } \\
\text { Baker }\end{array}$ \\
\hline Yakutat Bay & 1980 & & 5 & Wolman ${ }^{2}$ \\
\hline Prince William Sound & $\begin{array}{l}1977 \\
1980 \\
1982\end{array}$ & & $\begin{array}{r}25 \\
31 \\
8\end{array}$ & $\begin{array}{l}\text { Hall } \\
\text { Reinke \& Wolman } 2 \\
\text { Hall }\end{array}$ \\
\hline Western Gulf of Alaska & 1980 & & 15 & Wolman ${ }^{2}$ \\
\hline Farallon Islands & 1983 & & 8 & Ostman \\
\hline
\end{tabular}


Table 3. Number of years individual whales were sighted in each regional habitat. Percentages of total whales are shown in parentheses

\begin{tabular}{|c|c|c|c|c|c|c|}
\hline Regional habitat & \multicolumn{5}{|c|}{ Years sighted } & Total whales \\
\hline Hawaii & $\begin{array}{l}521 \\
(86.3)\end{array}$ & $\begin{array}{c}65 \\
(10.8)\end{array}$ & $\begin{array}{l}11 \\
(1.8)\end{array}$ & $\begin{array}{l}6 \\
(1.0)\end{array}$ & $\begin{array}{c}1 \\
(0.2)\end{array}$ & 604 \\
\hline Mexico & $\begin{array}{c}43 \\
(100.0)\end{array}$ & & & & & 43 \\
\hline Southeastern Alaska & $\begin{array}{l}172 \\
(52.8)\end{array}$ & $\begin{array}{c}88 \\
(27.0)\end{array}$ & $\begin{array}{c}43 \\
(13.2)\end{array}$ & $\begin{array}{l}20 \\
(6.1)\end{array}$ & $\begin{array}{l}3 \\
(0.9)\end{array}$ & 326 \\
\hline Yakutat Bay & $\begin{array}{c}5 \\
(100.0)\end{array}$ & & & & & 5 \\
\hline Prince William Sound & $\begin{array}{c}47 \\
(86.0)\end{array}$ & $\begin{array}{c}7 \\
(12.2)\end{array}$ & $\begin{array}{c}1 \\
(1.8)\end{array}$ & & & 55 \\
\hline Western Gulf of Alaska & $\begin{array}{c}15 \\
(100.0)\end{array}$ & & & & & 15 \\
\hline Farallon Islands & $\begin{array}{c}8 \\
(100.0)\end{array}$ & & & & & 8 \\
\hline All regions & & & & & & 1056 \\
\hline
\end{tabular}

(Table 4). One whale was sighted in the Islas Revillagigedo, Mexico, during the winter of 1978 and in Hawaii during the winter of 1981. One whale was photographed in Yakutat Bay during 1980 and in southeastern Alaska in 1982. No movement was found between the feeding regions of southeastern Alaska, the Farallon Islands, Prince William Sound, and the western Gulf of Alaska during the studies reported here. A more recent study, however, found that 2 whales sighted in Prince William Sound during 1977 and 1980 were sighted in southeastern Alaska during the summer of 1984 (Baker et al. 1985). The movement between southeastern Alaska and Prince William Sound is shown in Fig. 1, but these matches were not included in the table of resights or the following statistics.

If humpback whales randomly assorted among the 5 feeding regions or between the 2 wintering grounds in alternate years, the chance of resighting a whale in a different region of a seasonal habitat should approximately equal the chance of resighting it across years in a single region. For example, a whale sighted in Hawaii one year should have an equal probability of being resighted in either Hawaii or Mexico in alternate years. Following the logic of mark-recapture analyses, the probability of an across-years resighting for a given region was calculated as

$$
\mathrm{p}=1 /(\mathrm{N}+1.96[\mathrm{SE}])
$$

where $\mathrm{N}$ and $\mathrm{SE}=$ weighted mean and standard error of the Petersen population estimate (Begon 1979). The weighted mean was calculated as

$$
\mathrm{N}=\frac{\sum \mathrm{M}_{1} \mathrm{n}_{1}}{\left(\sum \mathrm{m}_{\mathrm{i}}\right)+1}
$$

where $\mathrm{M}_{\mathrm{i}}=$ the number of whales sighted prior to year $i$ (whales at risk in year $i$ ); $n_{i}=$ number of whales sighted in year $i_{i} m_{i}=$ number of individuals resighted in year $i$. The standard error is given by

$$
\mathrm{SE}=N \sqrt{\frac{1}{\sum \mathrm{m}_{\mathrm{i}}+1}+\frac{2}{\left(\sum \mathrm{m}_{\mathrm{i}}+1\right)^{2}}+\frac{6}{\left(\sum \mathrm{m}_{1}+1\right)^{3}}}
$$

Using the cumulative sightings across all years, rather than only contiguous pairs of years, should result in an inflated estimate of the population since births and deaths in the population cause a general decline in resights across years (Seber 1982). An inflated population estimate will provide a conservative estimate of the across-years-within-region resighting probability. The use of the upper $95 \%$ confidence limit of the population estimate provides further assurance that the across-years-within-region resighting probability is conservative.

Among the feeding regions, only southeastern Alaska provided a sufficient sample size to estimate abundance and the probability of across-years-withinregion resightings (Table 5). The weighted mean of the Petersen estimate suggested a seasonal 'population' of 374 ( \pm 47 at the $95 \%$ confidence interval) individuals in southeastern Alaska. Using the inverse of the upper confidence limit as the across-years-within-region resighting probability $(1 / 421)$, it was then possible to determine the expected number of resights between 
Table 4. The regional exchange and migratory movement of humpback whales in the central and eastern North Pacific. Number of whales sighted in each regional habitat is shown in parentheses

\begin{tabular}{|c|c|c|c|c|c|c|c|}
\hline \multirow[t]{2}{*}{ Sighting region } & \multicolumn{6}{|c|}{ Resighting region } & \multirow[b]{2}{*}{$\mathrm{FI}$} \\
\hline & $\mathrm{HI}$ & $\mathrm{ME}$ & SEA & YB & PWS & WGA & \\
\hline Hawaii (HI) & $(604)$ & 1 & 65 & 3 & 8 & 4 & 0 \\
\hline Mexico (ME) & & $(43)$ & 1 & 0 & 1 & 0 & 1 \\
\hline Southeastern Alaska (SEA) & & & (326) & 1 & $0^{1}$ & 0 & 0 \\
\hline Yakutat Bay (YB) & & & & (5) & 0 & 0 & 0 \\
\hline Prince William Sound (PWS) & & & & & $(55)$ & 0 & 0 \\
\hline Western Gulf of Alaska (WGA) & & & & & & $(15)$ & 0 \\
\hline Farallon Islands (FI) & & & & & & & $(8)$ \\
\hline Total individuals & & & & & & & 971 \\
\hline
\end{tabular}

southeastern Alaska and the other feeding regions. For example, the expected number of resights between southeastern Alaska and Prince William Sound (42.6) was calculated by multiplying the number of photoidentified whales from southeastern Alaska (326) by the number of whales in Prince William Sound (55) and by the estimated across-years-within-region resighting probability (1/421). The expected number of resights with photographs from the remaining feeding regions were: 3.9 for Yakatat Bay; 11.6 for the Western Gulf of Alaska; and 6.2 for the Farallon Islands (Table 4). A Chi-square test showed that the observed values clearly differed from the expected values under the null hypothesis that whales randomly assorted among the feeding regions (Chi-square [3] = 105.9; $\mathrm{P}<0.005$ )

This process was repeated for the wintering grounds, using the across-years resighting data from Hawaii
(Table 6). The weighted mean of the Petersen estimate suggested a 'population' of 1627 ( \pm 307 at the $95 \%$ confidence interval) individuals that visited Hawaii across the study period. Based on this across-yearswithin-region resighting probability (1/1934), the number of identified whales from Hawaii (604), and from Mexico (43), the expected number of betweenregion resightings was 13.4 ; significantly greater than the single observed resight between Hawaii and Mexico (Chi-square [1] = 16.6; $\mathrm{P}<0.005$ ).

\section{Migratory destinations}

The photographs of individual whales from the 2 wintering grounds were compared to those from the 5 feeding regions in order to determine the migratory destinations of humpback whales in the central and

Table 5. Across-year resighting of whales in southeastern Alaska. See text for description of mark-recapture notation

\begin{tabular}{|c|c|c|c|c|c|c|}
\hline & \multicolumn{6}{|c|}{ Study year } \\
\hline & 79 & 80 & 81 & 82 & 83 & Sum \\
\hline Whales sighted $\left(n_{1}\right)$ & 83 & 122 & 147 & 175 & 45 & - \\
\hline Whales resighted $\left(\mathrm{m}_{1}\right)$ & - & 33 & 74 & 105 & 34 & 246 \\
\hline Sighted whales at risk $\left(M_{1}\right)$ & - & 83 & 172 & 245 & 315 & 326 \\
\hline
\end{tabular}

Table 6. Across-year resighting of whales in Hawaii. See text for description of mark-recapture notation

\begin{tabular}{|c|c|c|c|c|c|c|c|c|}
\hline & \multicolumn{8}{|c|}{ Study year } \\
\hline & 77 & 78 & 79 & 80 & 81 & 82 & 83 & Sum \\
\hline Whales sighted $\left(n_{1}\right)$ & 9 & 19 & 56 & 130 & 175 & 115 & 209 & - \\
\hline Whales resighted $\left(\mathrm{m}_{1}\right)$ & - & 1 & 5 & 7 & 23 & 31 & 42 & 109 \\
\hline Sighted whales at risk $\left(M_{1}\right)$ & - & 9 & 27 & 78 & 201 & 353 & 437 & 604 \\
\hline
\end{tabular}


Table 7. Observed and expected number of photographic resightings between seasonal habitats of the central and eastern North Pacific. Expected number of matches, shown in parentheses, were calculated from the between-seasonal-habitat resighting probability. See text for details. Abbreviations are given in Table 4

\begin{tabular}{|c|c|c|c|c|c|c|}
\hline \multirow[t]{2}{*}{ Wintering grounds } & \multicolumn{5}{|c|}{ Summering grounds } & \multirow[t]{2}{*}{ Total resights } \\
\hline & $\begin{array}{c}\text { SEA } \\
n=326\end{array}$ & $\begin{array}{c}\mathrm{YB} \\
\mathrm{n}=5\end{array}$ & $\begin{array}{c}\text { PWS } \\
\mathrm{n}=55\end{array}$ & $\begin{array}{l}\text { WGA } \\
n=15\end{array}$ & $\begin{array}{c}\mathrm{FI} \\
\mathrm{n}=8\end{array}$ & \\
\hline $\begin{array}{l}\text { Hawaii } \\
n=604\end{array}$ & $\begin{array}{l}65 \\
(61.8)\end{array}$ & $\begin{array}{l}3 \\
(1.0)\end{array}$ & $\begin{array}{c}8 \\
(10.4)\end{array}$ & $\begin{array}{l}4 \\
(2.8)\end{array}$ & $\begin{array}{l}0 \\
(1.5)\end{array}$ & $\begin{array}{l}80 \\
(77.5)\end{array}$ \\
\hline $\begin{array}{l}\text { Mexico } \\
\mathrm{n}=43\end{array}$ & $\begin{array}{c}1 \\
(4.4)\end{array}$ & $\begin{array}{l}0 \\
(0.1)\end{array}$ & $\begin{array}{c}1 \\
(0.7)\end{array}$ & $\begin{array}{l}0 \\
(0.2)\end{array}$ & $\begin{array}{l}1 \\
(0.1)\end{array}$ & $\begin{array}{l}3 \\
(5.5)\end{array}$ \\
\hline
\end{tabular}

eastern North Pacific. The comparison revealed extensive interchange between seasonal habitats (Table 7 ). Whales from Hawaii traveled to all of the feeding grounds in Alaska. The only feeding area where Hawaiian whales were not found was the Farallon Islands. Whales wintering in Mexican waters traveled to at least 3 of the 5 feeding grounds included in the study: southeastern Alaska, Prince William Sound, and the Farallon Islands. The whale that traveled to southeastern Alaska and the whale that traveled to the Farallon Islands were photographed near the Islas Tres Marias during 1980. The whale that traveled to Prince William Sound was photographed near the Islas Revillagigedo during 1978.

Following the procedure described earlier, the overall probability of resighting between seasonal habitats was determined from the total number of photographs from the wintering grounds (647), the total number from the summer feeding regions (409), and the total number of resights (83). This resighting probability (1/3188) was used to calculate the expected number of resights between each of the 2 wintering grounds and the combined sample of whales from the 5 feeding regions. Based on the results of a chi-square test, it was not possible to reject the null hypothesis that the combined sample of whales from all feeding regions was equally represented on each of the 2 wintering grounds (Chi-square [1] $=1.22 ; \mathrm{P}>0.25$ ).

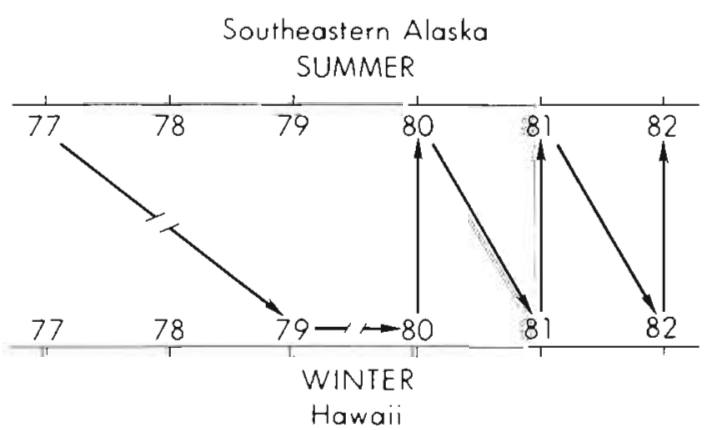

Fig. 2. Megaptera novaeangliae. Migratory transits of Animal \#022 between Hawaii and southeastern Alaska. Broken lines indicate the probable presence of undocumented transits
The between-seasonal-habitat resighting probability was also used to calculate the expected number of resights between each of the 2 wintering grounds and each of the 5 feeding grounds, separately (Table 7). Although the expected number of resights in some of the table's cells were too small (less than 1) to make a chi-square test appropriate, the table does suggest some trends. The observed number of resights between Hawaii and Yakutat Bay was unexpectedly high and the number between Mexico and southeastern Alaska was unexpectedly low. Given the small sample sizes from both regions, the single resight between Mexico and the Farallon Islands was unexpected. Given the large sample from Hawail, the absence of any resightings with the Farallon Islands was unexpected.

\section{Migratory transits}

Many of the photo-identified whales traveled between seasonal habitats more than once. The 65 whales seen in both Hawaii and southeastern Alaska made a total of 1151 -way transits between these 2 regions. A 1-way transit was considered to be any pair of sequential, though not necessarily consecutive, sightings in 2 different seasonal habitats uninterrupted by a sighting in a third region. The most extensive migratory transiting was shown by Animal \#022, a whale seen during $4 \mathrm{yr}$ in southeastern Alaska and during $4 \mathrm{yr}$ in Hawaii (Fig. 2). The 8 regional sightings indicated at least 6 transits (3 round-trips) between Hawail and southeastern Alaska. Although it is likely that Animal \#022 completed the migration between summer and winter grounds each year, only confirmed transits were included in this analysis. The only other repeated migratory returns were found between Hawaii and Prince William Sound, where 3 whales made round-trips.

One whale was seen in 3 regions during the study period. Animal \#232 was sighted in Glacier Bay, southeastern Alaska, during the summers of 1974 , 1975, 1976, and 1977 (Jurasz \& Palmer 1981a, b). It was 
next sighted in Yakutat Bay during the summer of 1980 and then returned to Glacier Bay in 1982. Finally, it was seen in Hawail during the winter of 1983. Later data (Baker et al. 1985) showed 1 more whale sighted in 3 regions. Animal \#301 was seen in Prince William Sound in 1977 and 1980 and in Hawail during the winter of 1983. Animal \#301 was next seen in southeastern Alaska during the summer of 1984.

\section{Fluke coloration}

Fluke photographs used in the previous comparisons were graded according to their proportion of pigmentation. Following a modification of the system used by Pike (1953), individual whales from each region were placed into 1 of 3 color phases (Fig. 3): (1) predominantly white, with white extending across more than $50 \%$ of each fluke; (2) moderately white, including all flukes with some discernible white covering less than $50 \%$ of each fluke; (3) dark, with no white pigmenta- tion except for what appeared to be scarring. To prevent a bias from frequently sighted whales, an individual was counted only once in each region that it was sighted.

Considering the total number of whales from all regions of the central and eastern North Pacific combined, the largest proportion of flukes were moderately white $(39 \%)$, and nearly equal proportions were predominantly white $(31 \%)$, or dark (30\%) (Table 8$)$. The proportion of flukes in each color phase, however, changed significantly from one region to another (Chi-square $[12]=51.58, p=0.0001$ ). Because the categories of fluke coloration were an ordered classification of an attribute along a continuous scale, parametric statistics were used to further analyze differences between regions (Snedecor \& Cochran 1967). For these analyses, each pair of flukes was assigned a score corresponding to its color phase: 1 for predominantly white, 2 for moderately white, and 3 for dark. An analysis of variance (ANOVA) also indicated significant overall differences in fluke coloration

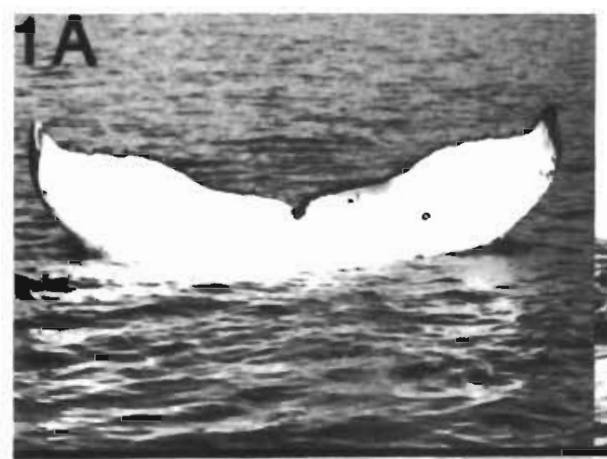

\section{B}
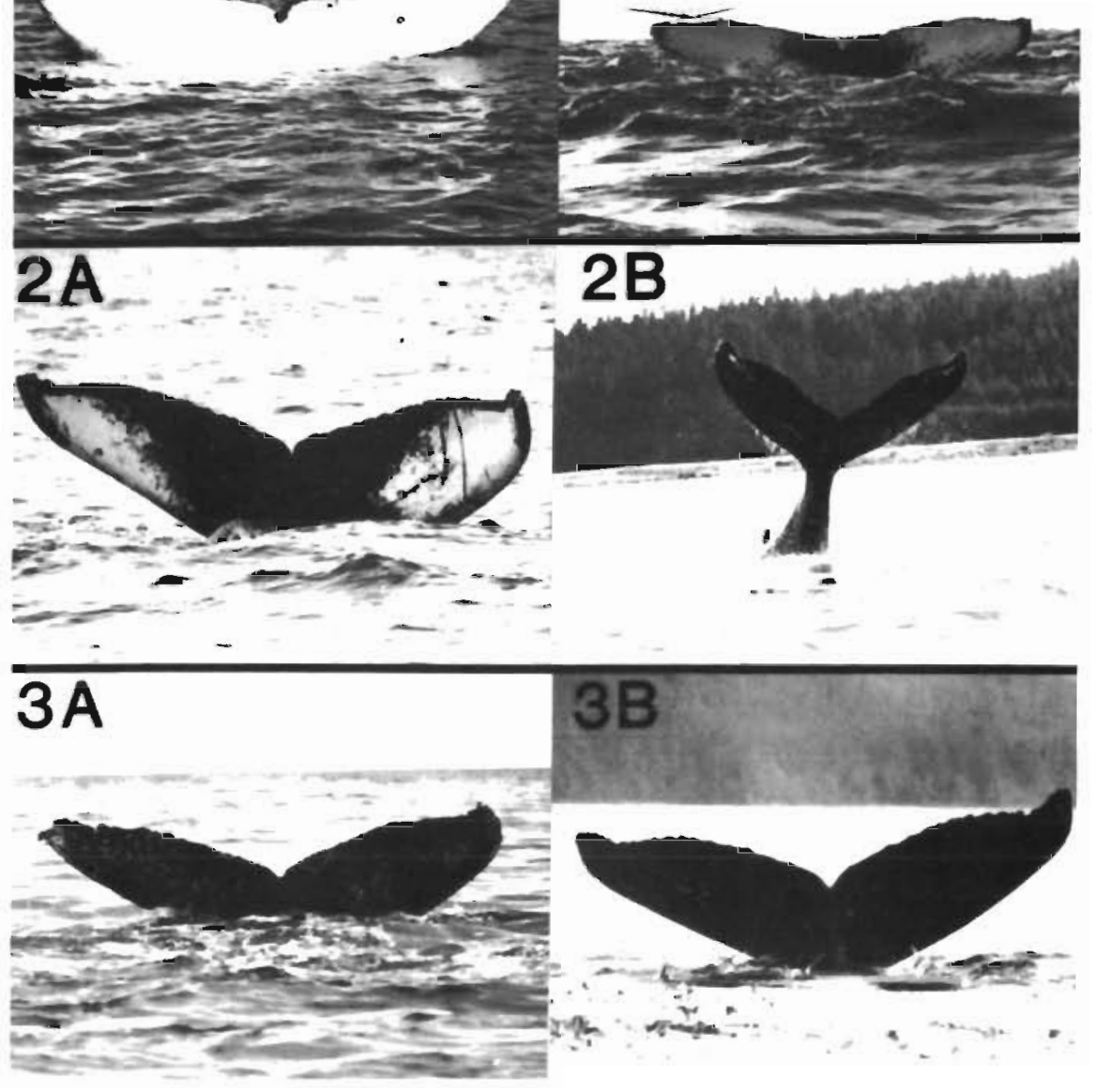

Fig. 3. Megaptera novaeangliae. Representative flukes of each color phase. $1 \mathrm{~A}$ and $1 \mathrm{~B}$ : predominately white; $2 \mathrm{~A}$ and $2 \mathrm{~B}$ : moderately white; $3 \mathrm{~A}$ and $3 \mathrm{~B}$ : dark 
Table 8. Fluke coloration of humpback whales in each regional habitat. Percentages of flukes in each color phase are shown in parentheses

\begin{tabular}{|c|c|c|c|c|}
\hline \multirow[t]{2}{*}{ Sighting region } & \multicolumn{3}{|c|}{ Color phase } & \multirow[t]{2}{*}{ Mean color phase } \\
\hline & 1 & 2 & 3 & \\
\hline Hawaii & $\begin{array}{l}199 \\
\text { (33) }\end{array}$ & $\begin{array}{c}252 \\
(42)\end{array}$ & $\begin{array}{c}153 \\
(25)\end{array}$ & 1.92 \\
\hline Mexico & $\begin{array}{c}18 \\
(42)\end{array}$ & $\begin{array}{c}12 \\
(28)\end{array}$ & $\begin{array}{c}13 \\
(30)\end{array}$ & 1.88 \\
\hline Southeastern Alaska & $\begin{array}{c}79 \\
(24)\end{array}$ & $\begin{array}{l}110 \\
(34)\end{array}$ & $\begin{array}{l}137 \\
(42)\end{array}$ & 2.18 \\
\hline Yakutat Bay & $\begin{array}{c}1 \\
(20)\end{array}$ & $\begin{array}{c}1 \\
(20)\end{array}$ & $\begin{array}{c}3 \\
(60)\end{array}$ & 2.40 \\
\hline Prince William Sound & $\begin{array}{c}21 \\
(38)\end{array}$ & $\begin{array}{c}24 \\
(44)\end{array}$ & $\begin{array}{c}10 \\
(18)\end{array}$ & 1.80 \\
\hline Western Gulf of Alaska & $\begin{array}{c}9 \\
(60)\end{array}$ & $\begin{array}{c}6 \\
(40)\end{array}$ & $\begin{array}{c}0 \\
(00)\end{array}$ & 1.40 \\
\hline Farallon Islands & $\begin{array}{c}0 \\
(00)\end{array}$ & $\begin{array}{c}3 \\
(37)\end{array}$ & $\begin{array}{c}5 \\
(63)\end{array}$ & 2.63 \\
\hline All regions & $\begin{array}{l}327 \\
(31)\end{array}$ & $\begin{array}{c}408 \\
(39)\end{array}$ & $\begin{array}{c}321 \\
(30)\end{array}$ & 1.99 \\
\hline
\end{tabular}

between the 7 regions $(F[6 / 1049]=6.99, p=0.0001)$. Multiple comparisons between the means suggested 2 basic groups differing at the 0.05 level of probability. The darker group included the Farallon Islands, southeastern Alaska, and Yakutat Bay. The lighter group included Mexico, Prince William Sound, Hawaii, and the western Gulf of Alaska.

The mean color scores from the feeding regions suggested a longitudinal trend, ranging from lighter in western-most regions to darker in eastern-most regions (Fig. 4). A regression of fluke coloration on longitude of the feeding region where the whale was sighted showed this trend to be weak but significant

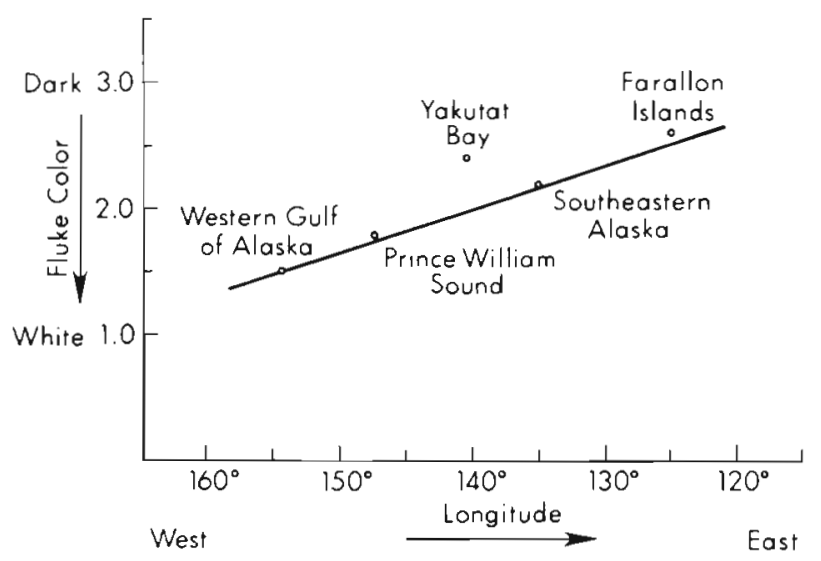

Fig. 4. Megaptera novaeangliae. Regression of average humpback whale fluke coloration from each feeding region on the region's longitude
$\left(\mathrm{F}[1 / 407]=24.32 ; \mathrm{p}=0.001 ; \mathrm{r}\right.$-square $=0.055 ; \mathrm{Y}^{\prime}=$ $6.806-0.034$ [longitude]). A longitudinal analysis of fluke coloration in the 2 breeding regions was not significant $(F \quad[1 / 645]=0.11 ; \quad \mathrm{p}=0.74 ; \mathrm{r}$-square $<0.001$ )

Yearly differences in the color phases were also examined for Hawaii and southeastern Alaska, the 2 regions with large sample sizes in more than 1 year. Using the 2 years with comparable effort and similar research methods (1980 and 1981 in Hawaii, 1981 and 1982 in southeastern Alaska) a nested ANOVA confirmed the difference between regions ( $F[1 / 2]=$ 434.63; $\mathrm{p}=0.005$ ) but showed no differences between the yearly samples within each region $(F[2 / 620]=$ $0.10 ; p=0.75)$.

\section{DISCUSSION}

\section{Migratory movement and population structure}

Humpback whales in the eastern and central North Pacific do not form 2 reproductively isolated stocks with separate feeding grounds corresponding to the Hawaiian and Mexican wintering grounds. Neither are they entirely nomadic, assorting randomly among different regions of each seasonal habitat in alternate years. Instead, the analysis of regional return, migratory destinations, and fluke coloration indicated that these whales, like humpback whales in the North Atlantic (Whitehead 1982, Katona et al. 1983, Martin et al. 1984), form several geographically-isolated 'feed- 
ing herds'. Individuals from these feeding herds intermingle in either Hawaij or Mexico during the breeding season but show little tendency to alternate between the 2 wintering grounds in different years. In most cases, the segregation or intermingling of whales from different regions was not absolute, but a matter of degree.

Strong site fidelity to a given feeding region was indicated by the large proportion of migratory returns to southeastern Alaska. Of the 326 photo-identified whales from this region, $47.2 \%$ were sighted in more than 1 of the 5 study years. Long-term studies of whales in Glacier Bay, southeastern Alaska, show that individual whales have returned to this locale for at least 10 separate seasons across a $12 \mathrm{yr}$ period (Jurasz \& Palmer 1981a, b, Perry et al. 1985). Site fidelity, as demonstrated by photographic resightings, is also reported for whales that summer in Prince William Sound (Hall 1979, Matkin \& Matkin 1981) and other parts of the Gulf of Alaska (Rice \& Wolman 1982).

Geographic segregation of feeding herds was indicated by the analysis of regional exchange. The comparison of photographs among the feeding regions resulted in only 1 match; southeastern Alaska to Yakutat Bay. Some movement or exchange between southeastern Alaska and Prince William Sound was shown by photographs from a 1984 study (Baker et al. 1985), but the number of matches was still far less than expected from the across-years-within-region resighting probability. Other comparisons of photo-identified whales from the North Pacific also revealed little or no exchange among summer habitats (Jurasz et al. 1981, Darling \& McSweeney 1985). Although the waters of southeastern Alaska seem to encompass the primary range of a single feeding herd (Baker et al. 1985), the exact geographic boundaries of each feeding herd are unknown and may involve some overlap.

The coloration of humpback whale flukes showed systematic differences across the 5 feeding regions. The clinal increase in the proportion of darkly pigmented flukes from the Gulf of Alaska eastward to the Farallon Islands was similar to that observed among stocks in the southern hemisphere (Omura 1953, Chittleborough 1965). Presumably, humpback whale coloration is genetically controlled, and coloration differences of whales in the southern hemisphere are thought to be the result of some genetic isolation (Gaskin 1982). Although feeding herds in the North Pacific intermingle to breed, a genetic cline could be maintained in one or more of the following ways: (1) mating within a feeding herd while still in the feeding region or during migration; (2) assortative mating between likecolored whales on the wintering grounds, similar to the assortative mating found among color phases of the lesser snow geese Anser caerulescens (Cooke et al.
1976); or (3) maternal inheritance of coloration and maternally-directed fidelity to a feeding region.

The intermingling of different feeding herds in Hawaii and Mexico was clearly demonstrated by the analysis of migratory movement and fluke coloration. Whales from different feeding regions traveled to the same wintering ground and whales from the same feeding region traveled to different wintering grounds. The average fluke coloration of whales from Hawaii and Mexico was similar and intermediate between the extremes of the feeding regions. The distribution of color phases in Hawaii and Mexico may reflect the intermingling of different feeding herds.

Although not statistically significant, a tendency for whales from feeding regions in the central North Pacific to travel to Hawaii and for whales from the eastern North Pacific to travel to Mexico is suggested by the migratory movement data. No whales from Hawaii were found near the Farallon Islands and no whales from the western Gulf of Alaska were found in Mexico. A longitudinal trend in selecting wintering grounds would be energetically economical if migratory travel follows a straight-line path between seasonal habitats.

The analysis of migratory return was inconclusive in determining the strength of fidelity to a single wintering ground. Only $13 \%$ of the whales photo-identified in Hawaii returned there across years. Based on the small sample of available photographs, no whales were resighted across years in Mexico. However, the proportion of resightings across years is a function of both sample size and the true abundance of animals in a region. Consequently, it is not strictly comparable between regions unless standardized by an independent estimate of abundance.

Some exchange between the Hawaiian and Mexican breeding grounds was confirmed by the resighting, across years, of at least 1 whale. However, this single match was far less than expected if whales alternated randomly between the 2 wintering grounds. A greater degree of interchange between wintering grounds is suggested by Darling \& Jurasz's (1983) report of 2 resightings, across years, among a much smaller sample of photographs from Hawaii and Mexico. Further photographic data from Mexico will be necessary to determine, with confidence, the extent of exchange among wintering grounds.

\section{Song exchange between wintering grounds}

Winn et al. (1981) and Payne \& Guinee (1983) have found that the structure of humpback whale songs from Hawaii and Mexico is essentially identical in a given year, but clearly different from the structure of songs 
shared by whales from other oceans. Because humpback whale song changes, to some degree, from year to year (Winn \& Winn 1978, Payne et al. 1983), whales that travel to Hawaii and Mexico presumably must be in acoustic contact at some point to learn the new song. Payne \& Guinee (1983) suggest 3 possible mechanisms for the exchange of songs between Hawail and Mexico: (1) singing on common summer feeding grounds or during migration to the wintering grounds; (2) individual singers visiting both wintering grounds during a single winter season, possibly forming a $4800 \mathrm{~km}$ long 'string' of migrating singers maintaining acoustic contact between the 2 regions; or (3) individual singers alternating between wintering grounds across years.

Although our data show that whales which winter in Hawaii and Mexico are found together in southeastern Alaska and Prince William Sound, singing is rarely heard during the summer season when most whales are found in these feeding regions. However, one of the authors' (Straley) observations of whales singing in southeastern Alaska during late fall and winter suggest an additional mechanism for song exchange on the feeding grounds. Whales found in southeastern Alaska 'late-season' groups also migrate to both Mexico and Hawaii and some individuals complete the southerly migration even after remaining in northern waters until as late as December (Baker et al. 1985). If the new song is established by late-season singers in northern latitudes, and these singers later travel to different wintering grounds, they could act as the vectors of song exchange. In this case, within- and between-year changes in the song could be communicated without direct interchange between wintering grounds.

Payne \& Guinee (1983) conclude that the analysis of song structure provides an accessible method of delineating stocks or reproductively-isolated groups of humpback whales. However, neither Winn et al. (1981) nor Payne \& Guinee (1983) demonstrate geographic variation in the songs of different sub-populations of humpback whales in the same ocean, only differences in the songs of populations.in different oceans. Until differences between the songs of sub-populations are found, the usefulness of this method remains in question. Additionally, the potential for whales to exchange songs while still in northern latitudes cautions against reliance on this technique to distinguish breeding groups.

\section{Social organization of a structured stock}

A whale stock is generally considered to be a relatively homogeneous sub-population which remains segregated from other stocks throughout the year and within which individuals have the potential to freely interbreed (Chapman 1974). This traditional definition is not adequate for the complex population structure of humpback whales in the North Pacific and the North Atlantic. We suggest instead that both geographic groups are best described as 'structured demes' (D. S. Wilson 1975, 1977) or, in keeping with whaling terminology, 'structured stocks'. Each structured stock consists of several feeding herds or 'ecological demes' which intermingle to breed on one or more wintering ground. Within a structured stock sets of whales associate with different probabilities in each seasonal habitat.

Seasonal changes in the probability of association between individual whales may have important implications for the evolution of social organization in this species (Baker 1985). Recent observations of humpback whale behavior indicate that sexual selection and ecological forces have acted independently in each seasonal habitat to create contrasting social systems (Baker \& Herman 1984b). On the wintering grounds, the social organization of humpback whales can be described as a polygamous mating system involving male-male competition for sexually mature females (Baker et al. 1981, Glockner-Ferrari \& Ferrari 1981, Tyack \& Whitehead 1983, Baker \& Herman 1984a, Mobley \& Herman 1985). In some feeding regions, the social organization is characterized by non-competitive and, at times, cooperative feeding behavior involving long-term associations between individuals (Baker et al. 1982, Weinrich 1983, Baker \& Herman 1984b, Baker 1985).

Ultimately, the driving force behind the evolution of social organization is the attempt by each individual in a population to maximize its inclusive fitness (Hamilton 1964, E. O. Wilson 1975). In a competitive mating system, an individual will decrease its inclusive fitness by competing with closely related individuals. In a cooperative feeding system, an individual will increase its inclusive fitness by cooperating with closely related individuals. For humpback whales, the inclusive fitness of individuals could be optimized by forming a structured stock in which individuals feed among closely related individuals but breed among distantly related or unrelated individuals. Matrilineal kinship within feeding herds could be maintained if fidelity to a feeding region is established when a calf first travels to the feeding grounds with its mother (Baker \& Herman 1984b, Martin et al. 1984). Observations of several individuals, first identified as calves, repeatedly returning to the same feeding region as their mothers, suggests that this is the case (Jurasz \& Palmer 1981a, b, Mayo \& Clapham 1983, Baker 1985). The congregation of several feeding herds onto a large wintering ground or the dispersal of a feeding herd to 
several wintering grounds would decrease the probability of competing with closely related individuals, help prevent excessive inbreeding, and assure an adequate choice of breeding partners during the short reproductive season. Baker \& Herman (1984b) suggest that the hypothesis of a structured stock could be further tested by determining the relatedness of individuals in feeding groups and breeding groups with immunological or isozymatic techniques.

\section{Management and exploitation of a structured stock}

In recent years, the abundance of humpback whale populations has been estimated by applying markrecapture models to photo-identification data (Baker et al. 1982, Whitehead 1982, Darling et al. 1983). These models assume that all individuals within a population have an equal probability of being marked and recaptured (Seber 1982). A structured stock, however, is composed of sets of whales with different probabilities of associations. This suggests that mark-recapture models must be applied with caution if they are to yield valid results. Geographically-isolated feeding herds can be estimated by sampling within their respective feeding regions where the probability of capture is equal for all members of the herd (Whitehead et al. 1980, Baker et al. 1982, 1983a, 1985, Whitehead 1982). The weighted mean estimate of 374 whales ( \pm 47 at the $95 \%$ confidence interval) in the southeastern Alaska feeding herd is surprisingly close to Baker et al.'s (1985) estimate based on Petersen estimates from contiguous years. Estimating the abundance of an entire structured stock, however, may be more difficult. Although the weighted mean estimate of 1627 whales ( \pm 307 at the $95 \%$ confidence interval) for the Hawaiian wintering congregation is in relatively close agreement with other recent estimates (Darling et al. 1983), these estimates should be considered with caution. If alternating between wintering grounds is common, whales must be marked and recaptured in all wintering grounds to assure an unbiased estimate.

Exploitation of a structured stock could have a differential impact depending on its seasonal timing. Local harvesting during the feeding season could quickly deplete a feeding herd. This may have been the case in southeastern Alaska where the harvests of shore-based whaling stations declined rapidly after only 1 or 2 good seasons (Bockstoce 1978, Rice 1978). On the other hand, shore-based whaling stations along migratory routes or near the wintering grounds were able to take greater numbers of humpback whales over many seasons (Nishiwaki 1959, Pike \& MacAskie 1969, Rice 1974, 1978).

\section{Stock segregation in the North Pacific}

Is there enough intermingling of feeding herds and exchange between wintering grounds to conclude that humpback whales in the North Pacific form a single structured population without reproductively-isolated stocks? Whaling biologists agree that most humpback whales throughout the North Pacific have darkly pigmented bellies and flanks (Pike 1953, Tomilin 1957. Nishiwaki 1959, 1960, 1962, Herman \& Antinoja 1977). Glockner-Ferrari \& Ferrari (1984) suggest that this is evidence for the existence of only 1 'stock' in the North Pacific. The uniformity of flank and belly coloration is puzzling given the diversity of fluke coloration. Unfortunately, whaling biologists, with the exception of Pike (1953), provide little quantitative data concerning the relation between ventral body coloration and fluke coloration. This absence of data is probably attributable to the whalers' practice of removing the flukes while at sea, before the whales were examined by biologists (Pike 1953). The limited data presented by Pike (1953) indicate that fluke coloration is not highly correlated with belly or flank coloration. Similarly, the data on variation in flipper coloration indicate little correlation with belly and flank coloration among the humpback whales which winter in Hawaiian waters (Herman \& Antinoja 1977, Glockner-Ferrari \& Venus 1983).

Discovery tag marking and recovery showed that humpback whales traveling to winter grounds south of Japan were found summering in the Bering Sea as far east as Unimak Island (Nishiwaki 1967). This easternmost documented feeding area of Asian whales is only a few hundred kilometers west of Chirikof Island, the westernmost documented summering ground of whales from Hawail. The potential overlap in the summering grounds of whales from Hawail and the western Pacific suggests the possibility of mixing throughout the North Pacific (Darling \& McSweeney 1985). However, observations from the southern hemisphere (Chittleborough 1965) indicate that some overlap of summer ranges is not necessarily evidence of significant exchange between stocks

Speculation aside, available data does little to confirm or deny Kellogg's (1929) original hypothesis of an American and an Asian stock in the North Pacific. The population structure of humpback whales in the eastern and central North Pacific, as described by individual movement, coloration, and song structure, is complex. Without comparable data from the western North Pacific, the relation between these 2 groups remains unknown, and our knowledge of humpback whale abundance, migratory behavior, and social organization remains incomplete. 


\section{NOTE ADDED IN PROOF}

Since the acceptance of this article an additional 12 photographs of whales from the feeding grounds off Central California were contributed by J. Stern (Moss Landing Marine Laboratory), R. Pitman (National Marine Fisheries Service, La Jolla), and M. Webber, I. Szczepaniak, and C. Ewaid (Gulf of Farallones Research Group). One of these whales, photographed by M. Webber off the Farallon Islands in July 1981, was sighted previously in Hawaii during March 1980, and subsequently in Hawaii during March 1982. These sightings provide the first documentation of a roundtrip migration between the Hawaiian wintering grounds and the feeding grounds off Central California. This observation supports the hypothesis that humpback whales from feeding herds throughout the eastern and central North Pacific congregate on the Hawaiian wintering grounds.

Acknowledgements. This research was supported in part by grants and contracts to L. M. Herman and C. S. Baker from the National Park Service, the National Marine Fisheries Service, and the Center for Field Research; to L. M. Herman from the National Science Foundation (Grant BNS 77-24943) and the University of Hawaii Sea Grant College Program (Institutional Grant Nos. NA79AA-d-00085 and NA81AA-d-00070); to W. S. Lawton from the Center for Field Research; and to G. D. Kaufman from the Pacific Whale Foundation and the Evjue Foundation. The views and opinions expressed in this paper do not necessarily reflect those of these agencies. C. S. Baker was also supported by fellowships from the National Wildlife Federation during much of this study. W S. Lawton was supported in part by salary from the National Marine Mammal Laboratory.

We thank the following people for their assistance in the field or during the data analysis: G. Bauer, B. Bays, S. Clark, M. Dahlheim, P. Dawson, M. Dobbins, the late Dr. T English, P. Forestell, Dr. C. Greenough, Dr. J. Greenough, C. Hart, K. Hazard, P. Hessing, J. Heyning, S. Hinkley, A. Hohn, T. Kieckhefer, J. Link, Dr. G. Losey, K. Lukins, Dr. J, Mobley, D. Rice, L. Sjolander, W. Stifel, M. Towner, B. Taylor, and Dr. K. Wood. We thank the following people and groups for logistical support: A. Lovaas of the National Park Service, Alaska Regional Office; D. Chase and G. Vequist of the Glacier Bay National Park and Preserve; K. Kreiger, Dr. G. Snyder, and Dr. B. Wing of the Auke Bay Laboratory; Dr. L. Jones, Dr. M. Tillman, and the late J. Johnson of the National Marine Mammal Laboratory; Dr. J. Wolz and Dr. D. Richards of the Kewalo Basin Marine Mammal Laboratory; I. Szczepaniak and M. Webber of the Gulf of the Farallones Research Project; The Oceanic Society, San Francisco Chapter; Kaypro Computer Corporation; American Cetacean Society; the U.S. Forest Service, Admiralty Island Monument; the Alaska State Troopers, Fish and Wildlife Protection Unit; and the U.S. Coast Guard, 13th District.

\section{LITERATURE CITED}

Andrews, R. C. (1916). Whale hunting with gun and camera. D. Appleton \& Co., New York, London

Baker, C. S. (1985). The population structure and social organization of humpback whales (Megaptera novaeangliae) in the central and eastern North Pacific. Ph. D. dissertation, University of Hawaii, Honolulu

Baker, C. S., Herman, L. M. (1981). Migration and local movement of humpback whales through Hawaian waters. Can. J. Zool. 59: 460-469

Baker, C. S., Herman, L. M. (1984a). Aggressive behavior between humpback whales, Megaptera novaeangliae, wintering in Hawaiian waters. Can. J. Zool. 62: 1922-1937

Baker, C. S., Herman, L. M. (1984b). Seasonal contrasts in the social behavior of humpback whales. Cetus 5 (2): 14-16

Baker, C. S., Herman, L. M., Stifel, W. S. (1981). Agonistic behavior in humpback whales: Evidence for male-male competition. 4th Biennial Conference on the Biology of Marine Mammals, San Francisco, Abstr., p. 7

Baker, C. S., Herman, L. M., Bays, B. G., Stifel, W. S. (1982). The impact of vessel traffic on the behavior of humpback whales in Southeast Alaska: 1981 season. Report to the National Marine Mammal Laboratory, Seattle, Washington

Baker, C. S., Herman, L. M., Bays, B. G., Bauer, G. B. (1983a). The impact of vessel traffic on the behavior of humpback whales in Southeast Alaska: 1982 season. Report to the National Marine Mammal Laboratory, Seattle, Washington

Baker, C. S., Herman, L. M., Stifel, W. S., Bays, B. G., Wolman, A. (1983b). The migratory movement of humpback whales between Hawaii and Alaska. 5th Biennial Conference on the Biology of Marine Mammals, Boston, Abstr., p. 5

Baker, C. S., Herman, L. M., Perry, A., Lawton, W. S., Straley, J. M., Straley, J. H. (1985). Population characteristics and migration of summer and late-season humpback whales (Megaptera novaeangliae) in southeastern Alaska. Mar. Mamm. Sci. 1 (3) : 304-323

Begon, M. (1979). Investigating animal abundance: Capturerecapture for biologists. University Park Press, Baltimore

Bockstoce, J. (1978). History of commercial whaling in Arctic Alaska. In: Alaska whales and whaling. Alaska Geographic $5(4): 17-54$

Chapman, D. G. (1974). Status of Antarctic rorqual stocks. In: Schevill, W. E. (ed.) The whale problem. Harvard University Press, Cambridge, p. 218-238

Chittleborough, R. G. (1965). Dynamics of two populations of the humpback whale Megaptera novaeangliae (Borowski). Aust. J. mar. Freshwat. Res. 16: 33-128

Cooke, F., Finney, G. H., Rockwell, R. F. (1976). Assortative mating in lesser snow geese (Anser caerulescens). Behav. Genet. 6: $127-140$

Darling, J. D., Jurasz, C. M. (1983). Migratory destinations of North Pacific humpback whales (Megaptera novaeangliae). In: Payne, R. (ed.) Communication and behavior of whales. Westview Press, Boulder, p. 359-368

Darling, J. D., McSweeney, D. J. (1985). Observations on the migrations of North Pacific humpback whales (Megaptera novaeangliae). Can. J. Zool. 63: 308-314

Darling, J. D., Gibson, K. M., Silber, G. K. (1983). Observations on the abundance and behavior of humpback whales (Megaptera novaeangliae) off West Maui, Hawaii, 1977-1979. In: Payne, R. (ed.) Communication and behavior of whales. Westview Press, Boulder, p. 201-222

Gaskin, D. E. (1982). The ecology of whales and dolphins. Heinemann Educational Books Ltd., London, Exeter

Glockner-Ferrari, D. A., Ferrari, M. J. (1981). Correlation of the sex and behavior of individual humpback whales, Megaptera novaeangliae, to their role in the breeding population. 4th Biennial Conference on the Biology of Marine Mammals, San Francisco, Abstr., p. 34 
Glockner-Ferrari, D. A., Ferrari, M. J. (1984). Reproduction in humpback whales, Megaptera novaeangliae, in Hawaiian waters. Rep. int. Whal. Commn (Special Issue) 6: 237-242

Glockner-Ferrari, D. A., Venus, S. C. (1983). Identification. growth rate, and behavior of humpback whale (Megaptera novaeangliae) cows and calves in the waters off Maui, Hawaii, 1977-1979. In: Payne, R. (ed.) Communication and behavior of whales. Westview Press, Boulder, p. 223-258

Hall, J. D. (1979). A survey of cetaceans of Prince William Sound and adjacent vicinity - their numbers and seasonal movements. In: Environmental Assessment of the Alaskan Continental Shelf. Final Reports of the Principal Investigators. NOAA-OCSEAP, Boulder (Biological Studies, Vol. 6, p. 631-726)

Hamilton, W. D. (1964). The genetical theory of social behavior, I, II. J. theor. Biol. 7 (1): 1-52

Herman, L. M. (1979). Humpback whales in Hawailan waters: A study in historical ecology. Pacif. Sci. 33: 1-15

Herman, L. M., Antinoja, R. C. (1977). Humpback whales in the Hawailan breeding waters: Population and pod characteristics. Sci. Rep. Whales Res. Inst. Tokyo, 29: 59-85

Herman, L. M., Forestell, P. H., Antinoja, R. C. (1980). The 1976/77 migration of humpback whales into Hawaiian waters: Composite description. Marine Mammal Commission Report MMC-77/19, Washington, D.C.

Herman, L. M., Tavolga, W. N. (1980). The communication systems of cetaceans. In: Herman, L. M. (ed.) Cetacean behavior: Mechanisms and functions. Wiley Interscience, New York, p. 149-209

Ivashin, M. V., Rovnin, A. A. (1967). Some results of the Soviet whale marking in the waters of the North Pacific. Norsk Hvaalfangst-tid 56 (6): 123-135

Jurasz, C. M., Palmer, V. P. (1981a). Censusing and establishing age composition of humpback whales (Megaptera novaeangliae) employing photodocumentation in Glacier Bay National Monument, Alaska. Report to the National Park Service, Anchorage, Alaska

Jurasz, C. M., Palmer, V. P. (1981b). Humpback whale (Megaptera novaeangliae) and vessel interactions in Glacier Bay National Monument, Alaska: 1976-1979. Report to the National Park Service, Anchorage, Alaska

Jurasz, C. M., Jurasz, V. P., Noble, E. L. (1981). An examination of the distribution of humpback whales (Megaptera novaeangliae) in southeast Alaska. Report to the State of Alaska Department of Fish and Game, Division of FRED, Juneau, Alaska

Katona, S., Baxter, B., Brazier, O., Kraus, S., Perkins, J., Whitehead, H. (1979). Identification of humpback whales by fluke photographs. In: Winn, H. E., Olla, B. L. (ed.) Behavior of marine animals, Vol. 3. Plenum Press, New York, p. 33-44

Katona, S., Whitehead, H. P. (1981). Identifying humpback whales using their natural markings. Polar Rec. 20 (128) 439-444

Katona, S., Balcomb, K. C. III, Beard, J. A., Whitehead, H., Matilla, D. (1983). The Atlantic humpback whale catalogue. 5th Biennial Conference on the Biology of Marine Mammals, Abstr., p. 53

Kellogg, R. (1929). What is known about the migrations of some of the whalebone whales. Ann. Rep. Smithson. Inst. for 1928 , p. $467-494$

Lawton, W. S., Rice, D. W., Wolman, A. A., Winn, H. (1979). Occurrence of southeastern Alaska humpback whales, Megaptera novaeangliae, in Mexican coastal waters. 3rd Biennial Conference on the Biology of Marine Mammals, Seattle, Abstr., p. 35
Lillie, D. G. (1915). Cetacea. British Antarctic (Tera Nova) Expedition, 1910. Nat. Hist. Rep. Zool. 1 (3): 85-124

Mackintosh, N. A. (1965). The stocks of whales. Fishing News (Books) Ltd., London

Mathews, L. H. (1937). The humpback whale, Megaptera nodosa. 'Discovery' Rep. 17: 7-92

Matkin, C. O., Matkin, D. R. (1981). Marine mammal survey of southwestern Prince William Sound 1979-1980. Report to the U.S. Fish and Wildlife Service, Anchorage, Alaska

Martin, A. R., Katona, S. K., Matilla, D., Hembree, D., Waters, T. D. (1984). Migration of humpback whales between the Caribbean and Iceland. J. Mammal. 65 (2): 330-333

Mayo, C. A., Clapham, P. J. (1983). Observations of humpback whale mother/calf pairs on Stellwagon Bank, Massachusetts: 1979-1983. 5th Biennial Conference on the Biology of Marine Mammals, Abstr., p. 64

Mobley, J. R., Herman, L. M. (1985). Transience of social affiliations among humpback whales (Megaptera novaeangliae). In the Hawaiian wintering grounds. Can. J. Zool. 63: 762-772

Nishiwaki, M. (1959). Humpback whales in Ryukyuan waters. Sci. Rep. Whales Res. Inst. Tokyo 14: 49-86

Nishiwaki, M. (1960). Ryukyuan humpback whaling in 1960. Sci. Rep. Whales Res. Inst. Tokyo 15: 1-15

Nishiwaki, M. (1962). Ryukyuan whaling in 1961. Sci. Rep. Whales Res. Inst. Tokyo 16: 19-28

Nishiwaki, M. (1967). Distribution and migration of the larger cetaceans in the North Pacific as shown by Japanese whaling results. In: Norris, K. S. (ed.) Whales, dolphins, and porpoises. University of California Press, Berkeley, p. $171-191$

Ohsumi, S., Masaki, Y. (1975). Japanese whale marking in the North Pacific, 1963-1972. Bull. Far. Seas Fish. Res. Lab. 12: $171-219$

Omura, H. (1953). Biological study on humpback whales in the Antarctic whaling areas IV and V. Sci. Rep. Whales Res. Inst. Tokyo 8: 81-101

payne, R., Guinee, L. N. (1983). Humpback whale (Megaptera novaeangliae) songs as an indicator of 'stocks'. In: Payne, R. (ed.) Communication and behavior of whales. Westview Press, Boulder, p. 333-358

Payne, K., Tyack, P., Payne, R. (1983). Progressive changes in the songs of humpback whales (Megaptera novaeangliae): A detailed analysis of two seasons in Hawaii. In: Payne, R. (ed.) Communication and behavior of whales. Westview Press, Boulder, p. 9-58

Perry, A., Baker, C. S., Herman, L. M. (1985). The natural history of humpback whales in Glacier Bay, Alaska. Report to the National Park Service, Alaska Regional Office, Anchorage, Alaska

Pike, G. C. (1953). Colour pattern of the humpback whales from the coast of British Columbia. J. Fish. Res. Bd Can. $10(6): 320-325$

Pike, G. C., MacAskie, I. B. (1969). Marine mammals of British Columbia. Bull. Fish. Res. Bd Can. 171: 1-54

Rice, D. W. (1974). Whales and whale research in the eastern North Pacific. In: Schevill, W. E. (ed.) The whale problem. Harvard University Press, Cambridge, p. 170-195

Rice, D. W. (1978). The humpback whale in the North Pacific: Distribution, exploitation, and numbers. In: Norris, K. S. Reeves, R. (ed.) Report on a workshop on problems related to humpback whales (Megaptera novaeangliae) in Hawaii. Report to the U.S. Marine Mammal Commission, Washington, D.C., p. 29-44

Rice, D. W., Wolman, A. A. (1982). Whale census in the Gulf of Alaska, June to August 1980. Rep. int. Whal. Commn 32: 491-498 
Scammon, C. M. (1874). The marine mammals of the northwestern coast of North America. John H. Carmany and Co., San Francisco

Seber, G. A. F. (1982). The estimation of animal abundance and related parameters. MacMillan Publishing Co., New York

Snedecor, G. W., Cochran, W. G. (1967). Statistical methods. lowa State University Press, Ames, lowa

Tomilin, A. G. (1957). Zveri SSSR i prilezhashchikh stran, Tom IX, Kitoobraznye (Mammals of the USSR and adjacent countries, Vol. 9, Cetacea). Akad. Nauk. SSSR, Moscow (Translated by the Israel Program for Scientific Translations, Jerusalem, 1967)

True, F. W. (1904). The whalebone whales of the western North Atlantic compared with those occuring in European waters; with some observations on the species of the North Pacific. Smithson. Contr. Knowl. 33: 1-318

Tyack, P., Whitehead, H. (1983). Male competition in large groups of wintering humpback whales. Behaviour 83: 132-154

Weinrich, M. T. (1983). Association patterns in a population of humpback whales (Megaptera novaeangliae). 5th Bien- nial Conference on the Biology of Marine Mammals, Boston, Abstr., p. 104

Whitehead, H., Harcourt, P., Ingham, K., Clark, H. (1980). The migration of humpback whales past the Bay de Verde Peninsula, Newfoundland, during June and July, 1978. Can. J. Zool. 58: 687-692

Whitehead, H. (1982). Populations of humpback whales in the Northwest Atlantic. Rep. int. Whal. Commn 32: 345-353

Wilson, D. S. (1975). A theory of group selection. Proc. natn. Acad. Sci. U.S.A. 72: 143-146

Wilson, D. S. (1977). Structured demes and the evolution of group-advantageous traits. Am. Nat. 111: 157-185

Wilson, E. O. (1975). Sociobiology: The new synthesis. Harvard University Press, Cambridge

Winn, H. E., Winn, L. (1978). The song of the humpback whale (Megaptera novaeangliae) in the West Indies. Mar. Biol. 47: $97-114$

Winn, H. E., Thompson, J. T., Cummings, W. C., Hains, J., Hudnall, J., Hays, H., Steiner, W. W. (1981). Song of the humpback whale - population comparisons. Behav. Ecol. Sociobiol. 8: 41-46

This article was submitted to the editor; it was accepted for printing on April 8, 1986 